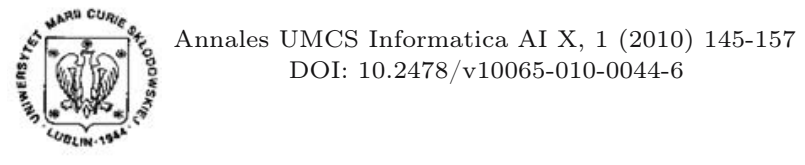

DOI: $10.2478 / \mathrm{v} 10065-010-0044-6$
Annales UMCS

Informatica

Lublin-Polonia Sectio AI

http://www.annales.umcs.lublin.pl/

\title{
Progress specialist IT knowledge among students based on learning blended learning
}

\author{
Robert Rajs* \\ Institute of technology, State Higher Vocational School, \\ ul. Wyspiańskiego 20, 38-400 Krosno, Poland.
}

\begin{abstract}
The article includes the analysis of the course whose aim is to present the potentialities of the system of virtual education Moodle[1], which is the basis for constructing e-Student platform owned by State Higher Vocational School in Krosno. The article presents the use of e-learning in the course 'Computer science in tourism' conducted at the Department of Tourism and Recreation in State Higher Vocational School in Krosno. The analysis of test practical task and final axam results computer science in tourism for the students of Tourism and recreation, which involved work in Voyager Travel, Hotel, Euroticket On-Line has clearly shown a strong correlation between the acquired computer science knowledge (good and very good grades) and the results of the final semester exam in Computer Science in Tourism e-course. The article describes the observations and conclusions drawn from the computer science courses run with a portal system based on the Moodle platform in the State Higher Vocational School Institute of Technology.
\end{abstract}

\section{Introduction}

The very concept of E-learning, as well as academic courses as such conducted in this system, still raise a lot of controversy in the Polish system of higher education. Although it is less and less common to question the important role of information technologies can play in the educational process, quite a considerable part of academic teachers, due to the concerns about the quality of education, have a lot of reservations about the application of information technologies in distance learning.

*robraj@pwsz.krosno.pl 
It is beyond any doubt today, however, that out of many forms of teaching, Elearning is becoming one of the most promising forms of education in the modern times. The development of telecommunication connections, together with the development of educational portals substantially contributed and still are contributing to improving the level of education of the young generation. Since 1990s we have observed in Poland continuous development of E-learning. The growth of 'information technology' society in our country, which, following the example of highly developed countries, drew attention to building the society 'based on knowledge' markedly influenced the development of distance education among the young generation. More and more interesting courses, training modules, questionnaires or on-line tests have been and still are designed.

E-learning - distance learning with computer technologies and the Internet is supporting the teaching process with personal computers, CD-ROMs and the Internet. It allows students to complete a course, training, or even higher studies without the physical presence in the lecture room. E-learning perfectly complements the traditional teaching process. E-learning is only one element of education and that is why education in the real time concerns a much broader range of services than E-learning.

E-learning is usually associated with teaching by means of the Internet or distance teaching. One of general definitions of E-learning says that it is" broad range of applications and processes of transmitting knowledge and skills via computer technologies". More and more commonly lecturers at higher education institutions introduce elements of E-learning into their courses. Fully multimedia courses are constructed which present the content of a course in a comprehensive way. The knowledge is presented by means of text, multimedia presentation, voice messages, brief instructional films or educational games. These forms of presentation are complemented by making chats or discussion forums available to students.

Due to the electronic form of the course I teach, some elements of the course Computer Science in Tourism were introduced on the educational portal E-student at our school. As part of the course has to take place in the computer laboratory, it was decided that $1 / 3$ of the course will be conducted on-line. Consequently, Blended learning, i.e. complementary learning was used. „Blended learning (complementary learning ) combines and interweaves two or several educational strategies, most commonly e-learning and direct teaching(traditional). It is particularly recommended and used in the cases where e-learning techniques do not fit the expected educational objectives(e.g. developing manual skills in laboratory classes).

Another definition: „Blended learning is a technique that facilitates learning through the effective combination of various means of communication, teaching models and learning styles based on transparent communication between all the participants of a given course"

This article contains the presentation of elements of E-learning in the course Computer Science in Tourism conducted in the Department of Tourism and Recreation 
at State Higher Vocational School. (SVHS) in Krosno. During the course two types of E-learning were used.

- Synchronous training - lectures conducted in the real time. The students communicated with the lecturer and the other participants of the training at the arranged time of the day. The subject matter of the virtual lecture was planned in advance during the classes run with full time students at SVHS in Krosno. The very training took from 1 to 2 hours ( it depended on the type of lecture).

- Asynchronous training - it is the most common type of E-learning. The students on the portal worked at their own pace. The students( especially extramural ones) individually allocated the amount of time they could spend on the portal, resulted from their professional work and other duties. The contact with the lecturer was maintained via the forum and e-mail.

The whole computer science course Computer Science in Tourism was based on the following forms of knowledge delivery:

- $\operatorname{Text}($ doc., txt).

- Files (PDF).

- Multimedia presentation.

- Flash presentation, e.g. the description of Voyager Travel system.

- Instructions (installation of booking programs in tourism).

- Voice messages (lecturer's recorded voice).

- Link to lecturer's www page with useful materials.

- On-line test for course participants.

- On-line chat for course participants.

- Internet forum for course participants.

The teaching tools implemented on the E-Student platform allow for the construction of courses in many different ways. It must be remembered, however, that the primary aim of creating a learning course is first of all passing on the knowledge. It means that you do not need to be an expert in every single element of the Moodle system to be effective in virtual teaching. This constitutes an incentive to use the possibilities of E-Student platform in teaching.

\section{The propositions of the analysis}

Below are presented the patterns of student participation in elements of E-learning during the testing of groups. Pattern 1 (so called Strong Links) was prepared on the basis of the analysis of about 100 students (full time/extramural studies), who, in percentage terms, spent more or less time participating in the course Computer Science in Tourism. This group includes all the students who participated in all the components of the course and covered portions of material ( computer systems in tourism) with the 
grades ranging from 3.5 to 5.0. This had a strong impact on the final grades in the practical exam in computer system at the end of the semester.

The group of so called "Weak Links" was a group of students who did not manage to handle all the electronic materials in the course which were made available to them by the lecturer. Those students' grades were between 3.5 and 4.0. It had a considerable impact upon their final exam grades. The students in this group did not participate in the discussion forum, chat and did not ask many questions via e-mail. Neither did they make use of electronic materials, such as lectures (text, multimedia presentation).

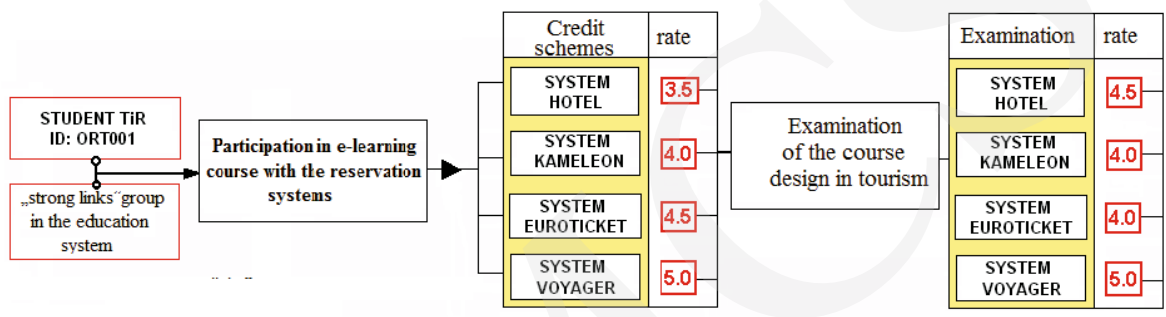

Fig. 1. "Strong links" group.

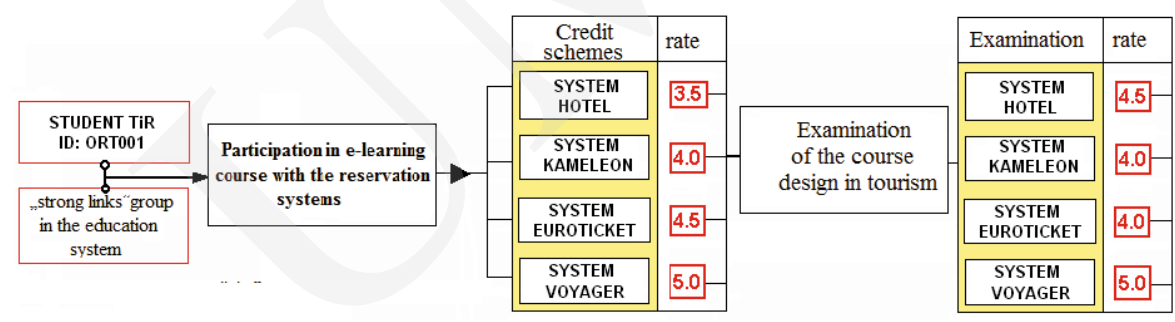

Fig. 2. "Weak links" group.

\section{Analysis}

The analysis of the two singled out groups of students makes it possible to draw several conclusions and confirm the research hypothesis made before the E-learning course.

Firstly, a full participation in the course (installation of computer systems in tourism, using program instructions, studying lectures, forum, asking questions, chat skillsharing ) had a huge impact on final grades, both in the case of getting credits and passing the final exam.

Secondly, all the gaps in the theoretical and practical knowledge ( selective use of E-student portal) is strongly correlated to the knowledge acquired during the course i.e. vocational education of students of Tourism and Recreation Dpartment. 
Table 1. „Strong links” group.

\begin{tabular}{|c|c|c|c|c|c|c|}
\hline & \multicolumn{6}{|c|}{$\begin{array}{l}\text { Analysis of exam results in computer systems in Tourism (content } \\
\text { correlation) in the Department of Tourism and Recreation, year } \\
\text { II }\end{array}$} \\
\hline $\begin{array}{l}\text { „Strong links" } \\
\text { group }\end{array}$ & \multicolumn{6}{|c|}{ Content correlation of exam results in computer systems in Tourism } \\
\hline Student's ID & $\begin{array}{l}\text { Test } \\
\text { No. } \\
1 \\
\text { Voyager }\end{array}$ & $\begin{array}{l}\text { Test } \\
\text { No. } \\
2 \\
\text { Euroticket }\end{array}$ & $\begin{array}{l}\text { Test } \\
\text { No. } \\
3 \\
\text { Kameleon }\end{array}$ & $\begin{array}{l}\text { Test } \\
\text { No. } \\
4 \\
\text { Hotel } \\
\end{array}$ & $\begin{array}{l}\text { Practical } \\
\text { exam }\end{array}$ & $\begin{array}{l}\text { Avarage } \\
\text { of all } \\
\text { subjects }\end{array}$ \\
\hline ORT004 & 5.0 & 6.0 & 5.0 & 4.0 & 5.0 & 5.0000 \\
\hline ORT005 & 4.0 & 4.0 & 4.5 & 3.0 & 4.5 & 4.0000 \\
\hline ORT006 & 4.0 & 4.0 & 4.0 & 4.5 & 4.0 & 4.1000 \\
\hline ORT015 & 4.0 & 4.5 & 4.5 & 4.0 & 5.0 & 4.4000 \\
\hline ORT027 & 5.0 & 5.0 & 5.0 & 4.0 & 4.0 & 4.6000 \\
\hline ORT032 & 4.0 & 5.0 & 3.5 & 4.5 & 4.0 & 4.2000 \\
\hline ORT034 & 3.0 & 4.0 & 4.5 & 4.0 & 4.5 & 4.0000 \\
\hline ORT039 & 4.0 & 5.0 & 5.0 & 3.0 & 3.5 & 4.1000 \\
\hline ORT055 & 5.0 & 3.0 & 5.0 & 4.0 & 3.5 & 4.1000 \\
\hline $\begin{array}{l}\text { Group } \\
\text { average }\end{array}$ & 4.2 & 4.5 & 4.5 & 3.8 & 4.3 & 4.2400 \\
\hline
\end{tabular}

\section{The presentation of the training (aims, propositions and results)}

In preparing modules of material for the course Computer Science in Tourism I employed my five year experience in running an Internet educational page with practical tasks, lectures and presentations for the students of several SHVS departments, which involved such courses as "Computer Science", "Computer Systems in Managing the Information in Tourism" or "Computer Systems".

Making use of the experience in operating the educational portal for 5 years (www.robraj.pwsz.krosno.pl) I must say that the presentation of the material in the form of Internet page may not meet the requirements of modern E-learning training.

It is no longer enough to present the elements of the training in the form of the text accompanied by a picture or to give step by step instructions how to install a computer program (e.g. Kameleon or Hotel 2009). It is necessary to make available to students, for example, short oral briefing, fragment of a brief educational film or discussion forum. There should be steps taken to make so called "on-line assistance" available for each participant of the training or course. It is also necessary to secure the synergy of the whole course. It is also crucial to respond to questions appearing on 
Pobrane z czasopisma Annales AI- Informatica http://ai.annales.umcs.pl

Data: 26/04/2023 16:33:24

150 Progress specialist IT knowledge among students based on learning blended learning

Table 2. „Weak links” group.

\begin{tabular}{|c|c|c|c|c|c|c|}
\hline & \multicolumn{6}{|c|}{$\begin{array}{l}\text { Analysis of exam results in computer systems in Tourism (content } \\
\text { correlation) in the Department of Tourism and Recreation, year } \\
\text { II }\end{array}$} \\
\hline $\begin{array}{l}\text { „Weak links" } \\
\text { group }\end{array}$ & \multicolumn{6}{|c|}{ Content correlation of exam results in computer systems in Tourism } \\
\hline Student's ID & $\begin{array}{l}\text { Test } \\
\text { No. } \\
1 \\
\text { Voyager }\end{array}$ & $\begin{array}{l}\text { Test } \\
\text { No. } \\
2 \\
\text { Euroticket }\end{array}$ & $\begin{array}{l}\text { Test } \\
\text { No. } \\
3 \\
\text { Kameleon }\end{array}$ & $\begin{array}{l}\text { Test } \\
\text { No. } \\
4 \\
\text { Hotel } \\
\end{array}$ & $\begin{array}{l}\text { Practical } \\
\text { exam }\end{array}$ & $\begin{array}{l}\text { Avarage } \\
\text { of all } \\
\text { subjects }\end{array}$ \\
\hline ORT009 & 5.0 & 4.0 & 4.0 & 4.0 & 5.0 & 4.4000 \\
\hline ORT011 & 4.0 & 4.0 & 4.5 & 4.0 & 4.5 & 4.2000 \\
\hline ORT043 & 3.5 & 4.0 & 3.5 & 4.5 & 4.0 & 3.9000 \\
\hline ORT031 & 4.0 & 3.0 & 4.0 & 3.0 & 3.5 & 3.5000 \\
\hline ORT001 & 3.0 & 5.0 & 5.0 & 3.0 & 3.0 & 3.8000 \\
\hline ORT050 & 4.5 & 4.0 & 3.5 & 3.0 & 4.0 & 3.8000 \\
\hline ORT049 & 4.0 & 3.5 & 5.0 & 5.0 & 3.5 & 4.2000 \\
\hline ORT017 & 3.0 & 4.0 & 3.5 & 3.0 & 3.0 & 3.3000 \\
\hline ORT007 & 4.0 & 4.0 & 5.0 & 4.0 & 3.5 & 4.1000 \\
\hline $\begin{array}{l}\text { Group } \\
\text { average }\end{array}$ & 3.8 & 4.0 & 4.2 & 3.8 & 3.7 & 3.8800 \\
\hline
\end{tabular}

the forum, be open to all forms of discussion, to all ideas and alternative approaches to finding a solution to a problem suggested by students. The teacher should stimulate the discussion, prompt and guide students towards covering the material in a particular way.

\section{The problems of implementing E-learning course}

The teacher of the course, while designing the course Computer Science In Tourism encountered a number of problems or difficulties which may appear in circumstances similar to those in which this from of education was introduced at State Higher Vocational School in Krosno.

(1) Technical problems.

(2) Problems of time and place.

(3) Problems (of human nature).

(4) Problems of mobility.

Technical problems are all kinds of limitations in access to the Internet that were encountered by the students selected for the course. Not everyone had an opportunity to participate in chat or discussion forum at the stage of "synchronous" training. 


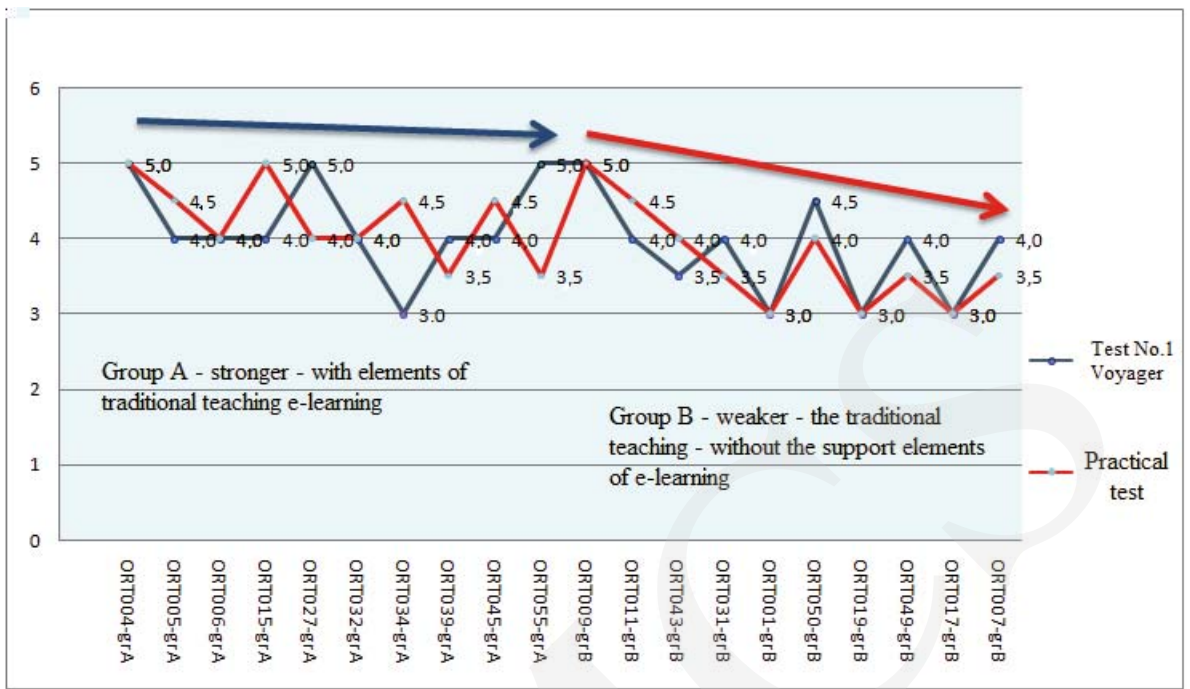

Fig. 3. Analysis of Voyager computer system results - Strong links group A/Weak Links group B.

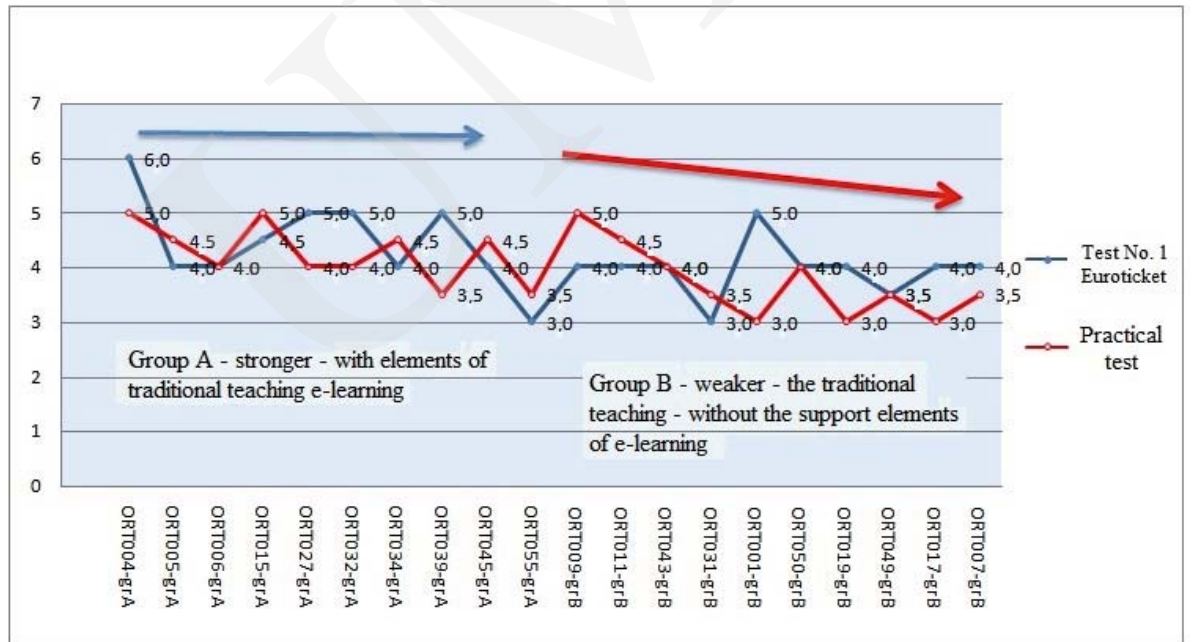

Fig. 4. Analysis of Euroticket computer system results - Strong links group A/Weak Links group B.

The second kind of problems, concerning time and place, was connected with limited opportunities (extramural students in most cases) to participate in so called "synchronous" form of E-learning at particular time or days of the week.

The problems of purely „human nature" are nothing but involvement or lack of it in the e-learning form of the course that I conducted. 
Pobrane z czasopisma Annales AI- Informatica http://ai.annales.umcs.pl

Data: 26/04/2023 16:33:24

152 Progress specialist IT knowledge among students based on learning blended learning

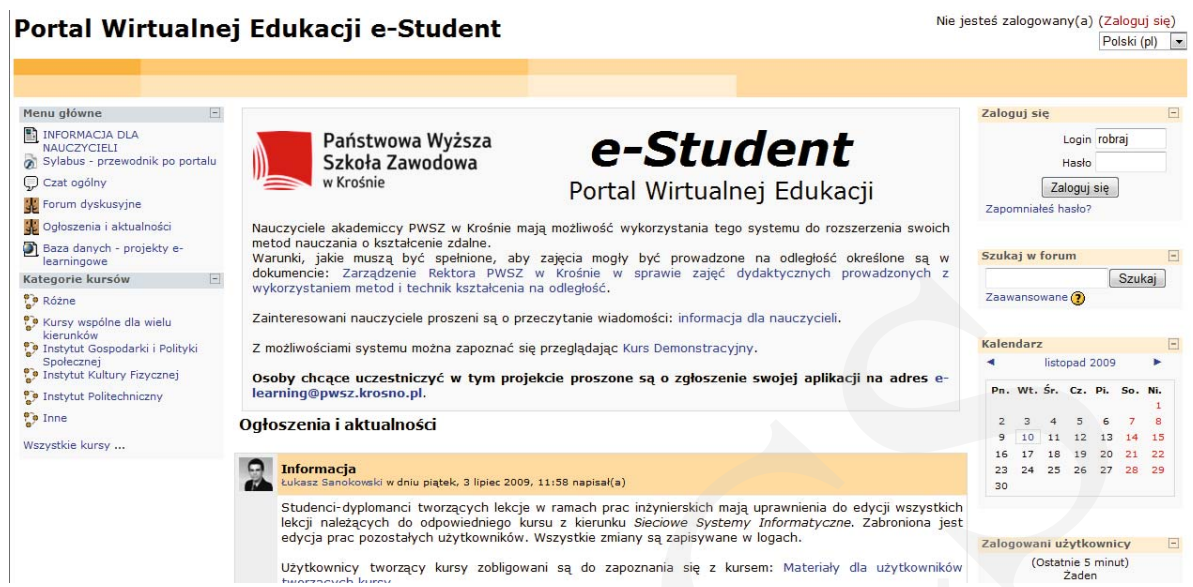

Fig. 5. E-student portal.

Systemy Informatyczne w Turystyce

Jesteś zalogowany(a) jako Robert Rajs (Wyloguj)

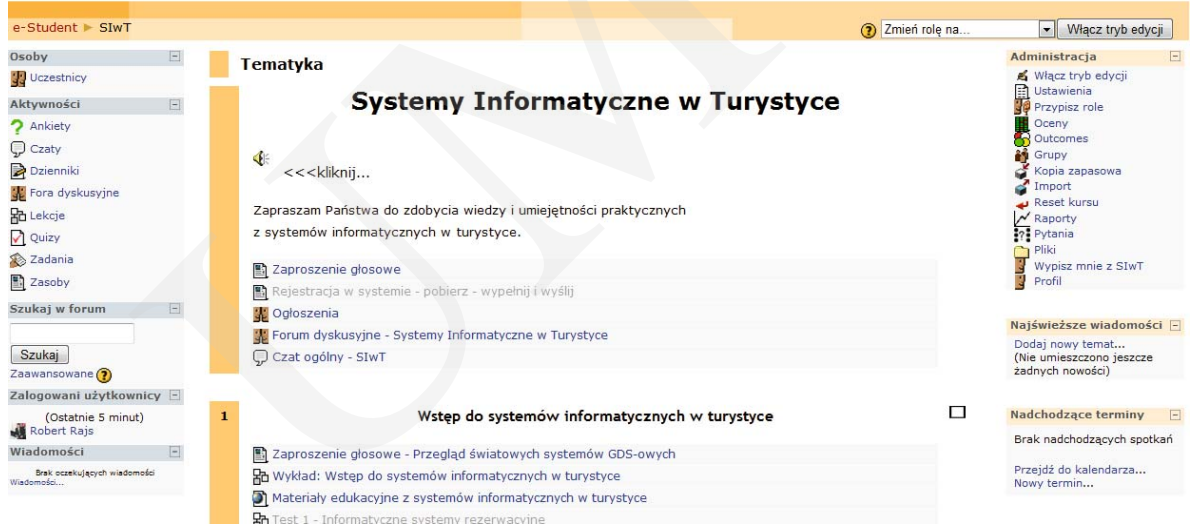

Fig. 6. The stage of placing the lesson on the portal.

\section{Conclusions}

This article presents the use of e-learning in the course 'Computer Science in Tourism' conducted in the Department of Tourism and Recreation at State Higher Vocational School in Krosno.

After two semesters of teaching, the system: portal system» E-Student-studentteacher» the relations in the system as well as grading system, its content and forms were analyzed. Conclusions concerning students' work in the system, teacher's work and his method of assessment make it possible to classify that kind of tool as an effective way of supporting the teaching process. 
Pobrane z czasopisma Annales AI- Informatica http://ai.annales.umcs.pl

Data: 26/04/2023 16:33:24

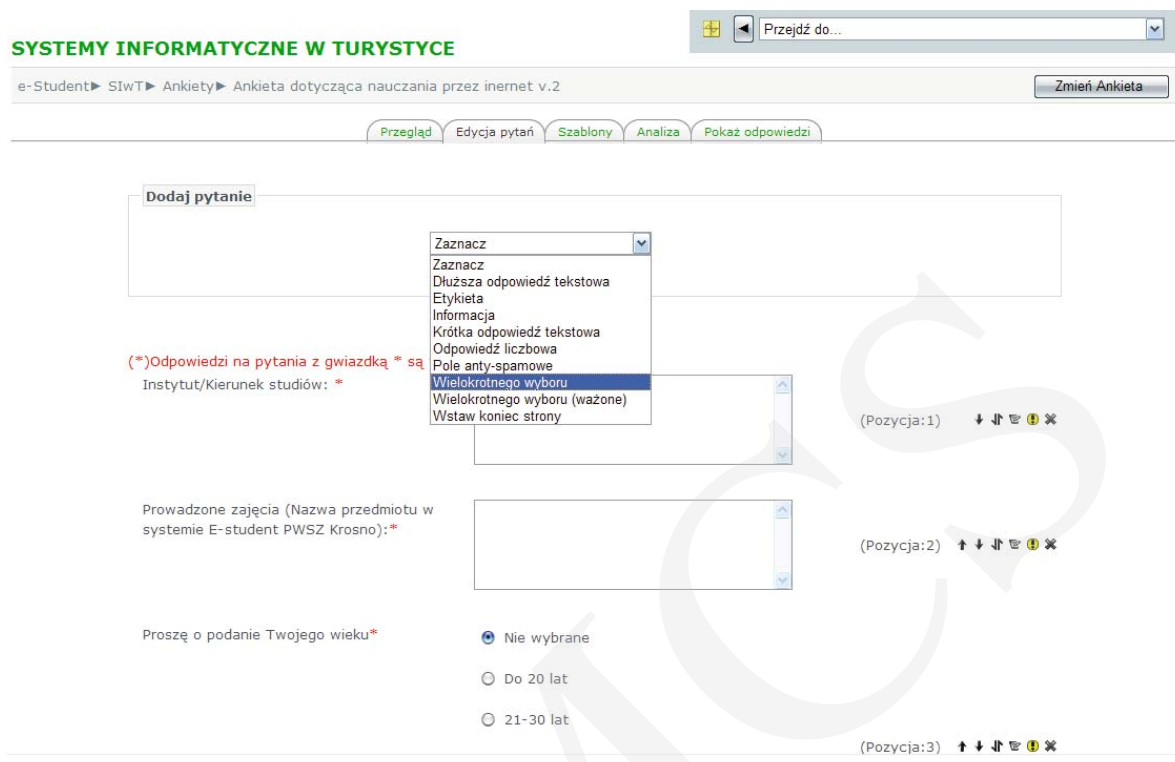

Fig. 7. Designing a test of competence in the course Computer science in tourism.

\section{Systemy Informatyczne w Turystyce}

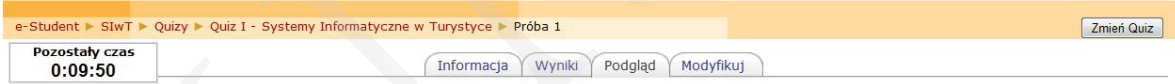

Podgląd Quiz I - Systemy Informatyczne w Turystyce

\section{Zacznij od nowa}

Studenci będa widzieć ten quiz w "bezpiecznym" oknie

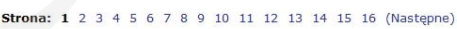

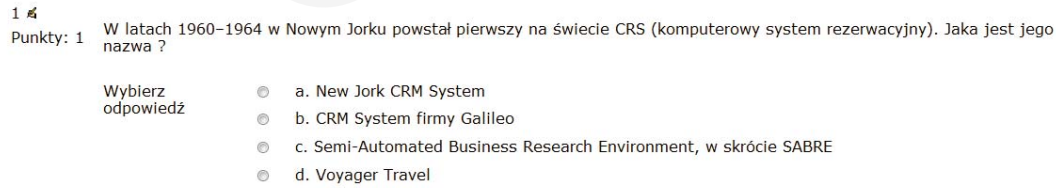

Fig. 8. On-line quiz In Progress. Timer on (left upper corner).

There has been a lot of research done to assess the effectiveness of E-learning. It is not my aim to prove that effectiveness. My research was aimed at verifying the knowledge and computer skills on the basis of specialist computer systems on the tourist market. 
The specific objective was to investigate how the implementation of varied forms of presentations influenced the quality of teaching in this department. The other specific objective was to assess the influence of increased amount of time spent on the portal, intensity of exchanging comments on the forum and chat upon the ability to operate booking systems in tourism. On the basis of test and practical tasks results among the students at the department of Tourism and Recreation and the final exam in the course Computer Science In Tourism, which involved working with Voyager Travel, Euroticket programs OniLine, the following conclusions have been drawn.

There is a clear correlation between the acquired knowledge in computer science (good and very good grades) and the final semester grades in the course Computer Science in Tourism.

Within four semesters, the research covered around 250 students who participated in two computer science courses.

The theoretical and practical knowledge was tested with sets of tests, sets of practical tasks and questions in the final exam in a given subject. Each group had the same sets of questions and tasks.

The difference was that group A and group B acquired knowledge in two different ways. Group A did test tasks, computer problem tasks with the use of SHVS Krosno estudent portal. Group B, in turn, had no access to the portal. They acquired knowledge through participating in classes ( just like group A) but other areas of knowledge were acquired by them in the way they chose (consultations in the laboratory, library, reading hall, the internet).

The analysis of the practical exam results proved that granting students access to the portal through preparing so called problem tasks allowed the students in group A to acquire knowledge much more effectively than the students in group B.

It should be stressed at this point that the time devoted to group B students was longer by $1 / 3$ as compared to group A. The participants for the two groups were selected at random. In order to confirm the hypothesis the analysis was checked again in the current academic year. The hypothesis was confirmed. Again group A turned out to be a group of "Strong Links", which was exhibited by active involvement in doing tests, short quizzes, and problem tasks.

The effectiveness of the conducted on-Line course, as exemplified by the course Computer Science in Tourism consists in the following elements:

- Acquaintance with the course participants' knowledge, their consultation needs.

- Constructing a course with clearly defined objectives and getting the students at the Department of Tourism and Recreation acquainted with them.

- Paying special attention to the graphic layout of the course; graphic layout should facilitate navigation and learning.

- It is necessary to take into consideration students' actual skills, like operating a computer, and in the case of using audio and video files or web pages links taking into account the equipment constraints. 
- Flexibility of the portal - adjusting it to students' individual needs, interests and priorities. These cannot, however, become the objectives as such; knowledge must be expanded in the real time and adjusted to the educational requirements.

- Access to technical service through constant technical support for the students of Tourism and Recreation Department.

- Installing links to various branch web pages specializing in information management in tourism and list of stores enabling students to broaden their general knowledge.

- Constant updating of information on SHVS E-student portal.

This paper presents the analysis of the implementation process of e-learning platform E-student, the aim of which is measuring the effectiveness of the teaching process in the Department of Tourism and Recreation at State Higher Vocational School in Krosno. The reasons for carrying out such an analysis are growing expectations of employers towards our school's graduates and information technologies inevitably entering every field of human activity, including travel offices, tourist information offices and others.

At the same time, the e-learning system, which is based on a uniform teaching program in the department chosen by the author of this paper, would secure an automatic measurement of teaching effectiveness, much more extensive and faster than any of those found in traditional forms of teaching.

The research conducted by different scientific and educational institutions shows that e-learning is as effective as traditional methods of teaching. The teacher in e-learning is "virtual, that is, he does not have a direct contact with the student, it is not necessary to conduct classes at particular time of the day and the student can learn at any time convenient for him. The learners can adjust then the time of the course to their pace of learning, which, forces them to work harder and longer though.

In many cases, students involved in the traditional form of teaching ( extra mural students, in particular) wanted to have additional consultations at school, but it was impossible due to their duties outside school. The introduction of discussion forum and chat related to the course resulted in an increased number of queries, comments and skill sharing with the teacher.

The effectiveness of learning in the traditional model of teaching decreases with time if the pace of learning is imposed by the teacher, which has been proved by my observations while teaching in the Department of Tourism and Recreation.

Different forms of distance learning, supported by technical aids allow for more innovative means of transferring knowledge and provide new opportunities to modernize the schemes of selecting the teaching materials.

E-learning, or teaching with computer is a challenge faced not only by the higher education in Poland (including State Higher Vocational Schools) but also by the Polish economy, for which the change of professional profile will determine its further progress in modern Europe. 
It seems then that the traditional method of teaching with "a piece of chalk and blackboard" will prove to be insufficient in the near future and more and more often the electronic net will be used for transmitting teaching materials. Teachers will face the problem of measuring the effectiveness of teaching by means of e-learning.

\section{References}

[1] Rajs R., Informatyczne systemy rezerwacyjne w turystyce (Wyd. PWSZ, Krosno, 2007): 152 .

[2] Materiały edukacyjne portalu edukacyjnego PWSZ Krosno - E-Student, http://www.e-learning.pwsz.krosno.pl/.

[3] Materiały edukacyjne systemów rezerwacyjnych w turystyce: Voyager Travel, Kameleon, Hotel 2009.

[4] Bartkowiak J., Metodologia projektowania szkoleń e-learning, Akademia on-line. (Wyd. WSH-E, Łódź, 2005): 16-24.

[5] Gładysz T., Hauke K., Owoc M., Ocena wiedzy jako funkcja edukacji zdalnej, Wirtualna edukacja po polsku, Baborski A., Kubiak M. J., Computerworld 26(438) (2000).

[6] Pozyskiwanie wiedzy z baz danych, Prace Naukowe AE nr 850 (Wydawnictwo Akademii Ekonomicznej we Wrocławiu (Wrocław, 2000).

[7] Kubiak M. J., Wirtualna edukacja po polsku, Computerworld 26 (2000): 438.

[8] Nycz M., Smok B., Zarządzanie wiedzą w systemach nauczania zdalnego, Komputerowo zintegrowane zarządzanie t. 2, Knosala R. (WNT, Warszawa, 2003): $21-35$.

[9] Nycz M., Smok B., Wiedza w Systemie E-learning, E. Niedzielska, H. Dudycz, M. Dyczkowski.

[10] Nowoczesne technologie informacyjne w zarządzaniu, Prace Naukowe nr 986 AE we Wrocławiu (Wrocław, 2003).

[11] Nycz M., Nauczanie wirtualne a wiedza, Komputerowo zintegrowane zarządzanie t.2, Knosala R. (WNT, Warszawa, 2003): 22-28.

[12] Osiński Z., Możliwości jakie stwarzają platformy e-learning w edukacji szkolnej, Gazeta IT 1 (2004): 20.

[13] Smok B., Nauczanie zdalne jako strategia kształcenia, Komputerowo zintegrowane zarządzanie t. 2, Knosala R. (WNT, Warszawa, 2003): 11-25.

[14] Hyła M., Przewodnik po e-learningu (Oficyna Ekonomiczna, Kraków, 2005): 4-33.

[15] Kushtina E., Koncepcja otwartego systemu informacyjnego nauczania zdalnego (Wyd. Politechniki Szczecińskiej, Szczecin, 2006): 8-43.

[16] Heinze A., Heinze C., Procter 2004 reflections on the use of blended learning. Education in a Changing environment, Materiały z konferencji na Uniwersytecie Salford, Education Development Unit. 
[17] Zając M., Stanisławska-Mischke A., Zakres i standardy oceny jakości e-kursów, Wybrane zagadnienia e-edukacji, Madey J., Rudak L. (WNT, Warszawa, 2008): $10-15$.

[18] Ryl-Zaleska M., Metody oceny efektywności kształcenia online, materiały z konferencji: Rozwój e-edukacji w ekonomicznym szkolnictwie wyższym (Warszawa, 2005): 5-17. 